\title{
PENGARUH LOGO KEMASAN PRODUK KOSMETIK SEBAGAI PENJELASAN KRITERIA PRODUK PEMAKAIAN DAN TINGKAT PENGETAHUN KEMASAN PRODUK TERHADAP REPURCHASE INTENTION (STUDI KASUS IBU-IBU/REMAJA CAKRAWALA II TJ PRIOK, KEC. KOJA JAKARTA UTARA)
}

\author{
Ana Ramadhayanti \\ Universitas Bina Sarana Informatika Bandung \\ Jl. Sekolah Internasional No.1-6, Cicaheum, Kiaracondong, Bandung 40291 \\ Email: Ana.rdx@bsi.ac.id
}

\begin{abstract}
Abstrak: Semakin banyaknya produk kosmetik yang berkembang dimasyarakat secara tidak langsung membuat konsumen ingin mencoba produk tersebut. Sampai saat ini produk kosmetik yang berkembang dimasyarakat beberapa diantaranya tidak memiliki logo atau simbol pada produk kemasan. Namun meskipun terdapat logo dikemasan terkadang ada beberapa konsumen yang tidak mengetahui arti dari logo atau symbol yang tertera dikemasan kosmestik tersebut. Padahal pencantuman simbol atau logo tersebut pada dasarnya sangat penting terutama untuk mengetahui kandungan yang terdapat pada produk, masa kadarluwarsa, kemasan produk berbahan ramah lingkungan atau tidak, dan cara penggunaan dari produk tersebut. Tujuan penelitian ini pada dasarnya untuk mengetahui pengaruh Logo Kemasan Produk Kosmetik Sebagai Penjelasan Kriteria Produk Pemakaian Dan Tingkat Pengetahun Kemasan Produk Terhadap Repurchase Intention. Penelitian ini menggunakan tipe penelitian survei, sedangkan metode penelitian yang digunakan adalah kuantitatif. Berdasarkan hasil penelitian didapatkan keseimpulan bahwa Logo Kemasan Kosmetik berpengaruh secara positif dan signifikan terhadap Repurchase Intention. Sementara itu untuk Pengetahuan berpengaruh positif dan signifikan terhadap Repurchase Intention. Diharapkan dari hasil penelitian ini masyarakat akan lebih waspada dan cermat sebelum membeli produk kosmetik.
\end{abstract}

Kata kunci: Kosmetik; logo; symbol; kemasan; pengetahuan produk.

\begin{abstract}
The growing number of cosmetic products that grow in the community indirectly make consumers want to try the product. Until now cosmetic products are growing in the community some of them do not have a logo or symbols on packaging products. However, although there is a logo packaged sometimes there are some consumers who do not know the meaning of the logo or symbol contained cosmestic packed them. Whereas the inclusion of symbols or logos is basically very important, especially to determine the content contained in the product, the lifetime of the product, packaging of products made from environmentally friendly or not, and how the use of the product. The purpose of this study basically to determine the effect of Cosmetic Products Packaging Logo as Explanation of Product Criteria Usage And Level Of Knowledge Of Product Package To Repurchase Intention. This research use survey type of research, while research method used is quantitative. Based on the research result, it is concluded that Cosmetic Packaging Log has positive and significant effect on Repurchase Intention. Meanwhile, Knowledge has positive and significant impact on Repurchase Intention. It is expected that from the results of this study people will be more vigilant and careful before buying cosmetic produc.
\end{abstract}

Keywords: Cosmetics; logo; symbols; packaging; product knowledge.

\section{PENDAHULUAN}

Kecantikan memang menjadi dambaan bagi setiap wanita, baik remaja ataupun orang tua. Banyaknya produk kosmetik yang masuk ke Indonesia maupun buatan dari Indonesia yang illegal. Berbagai produk kosmetik yang tanpa ijin BPOM sangat disangsikan kesehatan bagi para pengguna. Meskipun Badan Pengawasan Obat dan Makanan (BPOM) secara rutin telah mengamankan dan memusnahkan barang-barang illegal tersebut, namun tetap saja tidak membuat jera para pelaku. Oleh sebab itu kita, sebagai konsumen ditutut harus lebiah memahami produk kosmetik apa yang aman digunakan oleh konsumen. Selain melihat kode kadaluwarsa, ada beberapa logo atau symbol yang biasa tertera pada produk kemasan kosmetik tersebut. Teliti sebelum membeli merupakan langkah awal yang dilakukan oleh konsumen dalam memilih produk. Berdasarkan data yang diperoleh dari beritagar.id terdapat beberapa produk kosmetik impor yang belum mendapat izin masuk dari BPOM.

Berdasarkan hasil oleh data diketahui bahwa beberapa kosmetik diimpor yang belum mendapat izin dari BPOM diantaranya dari Tiongkok (34 produk), Prancis (20 produk), Taiwan (13 produk), Jerman dan Korea Selatan masing-masing sembilan produk, serta Indonesia (4 produk) dan Singapura (1 produk). Mengingat masayarakat Indonesia yang masih ketergantungan menggunakan produk kosmetik dari luar maka sebagai konsumen seharusnya mengetahui makna logo yang tertera dalam kemasan produk. 


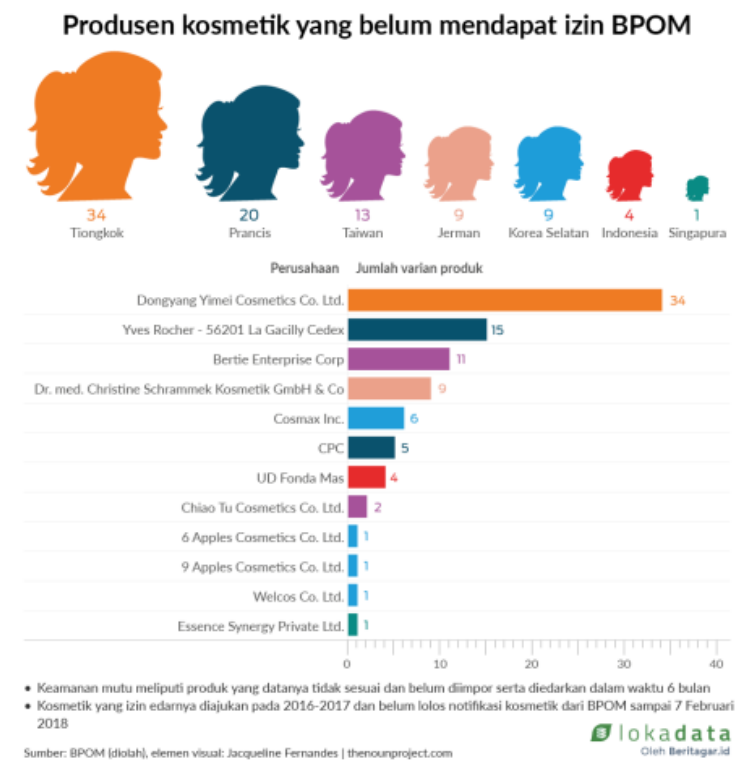

Sumber: BPOM (diolah), elemen visual: Jacqueline Fernandes $\mid$ thenounproject.com

Gambar 1. Produsen Kosmetik yang Belum Mendapat Izin BPOM

Menurut (Kaihatu 2014)Penggunaan produkproduk yang telah dikemas tidak lepas dalam kehidupan kita, seperti makanan dan minuman, kosmetik, obat-obatan, ataupun produk-produk kebutuhan rumah tangga lainnya. Maka, kita selalu "bertemu" dengan kemasan. Sekali lagi, kemasan berperan penting sebagai pelindung produk yang ada di dalamnya. Oleh karena peranan yang penting itulah, maka kemasan haruslah dibuat dengan memenuhi standar yang tinggi dan telah memenuhi syarat-syarat yang sudah ditetapkan, baik oleh BPOM ataupun oleh lembaga-lembaga Internasional, seperti CODEX, ISO, (GMP, HACCP), CE, Ecolabelling, dan sebagainya. Dengan demikian, produk-produk yang dikemas tersebut dapat terlindungi dan dikonsumsi dengan baik, sehat, dan aman.

Hal serupa juga dijelaskan dalam penelitian yang dilakukan oleh (Susetyarsi 2017) Kemasan merupakan salah satu strategi produk yang dipakai oleh perusahaan untuk menampakkan produk agar lebih menarik baik dari segi bentuk, warna, sehingga produk dapat terjaga kualitasnya. Saat ini perusahaan sudah banyak yang sadar untuk menciptakan kemasan produk yang menarik. Hal ini dikarenakan perusahaan menggunakan bungkus sekaligus untuk promosi. Produk-produk yang terpajang di rak- rak supermarket harus dibuat semenarik mungkin sehingga konsumen akan tertarik dan mengambilnya sebagai barang belanjaannya. Semakin banyak tempat belanja yang self service maka bungkus sangat penting artinya baik bagi produsen maupun bagi konsumen. Bagi konsumen dengan bungkus produk yang menarik dan spesifik maka akan lebih mudah konsumen untuk mendapatkan barang yang dimaksud.

Masing-masing logo pada dasarnya memiliki arti tersediri, namun yang jadi permasalahan adalah apakah masing-masing orang memiliki pengetahuan seputar makna dari logo tersebut. Terkadang sebagai wanita untuk membeli kosmetik terkadang yang menjadi bahan pertimbangan utama adalah cocok atau tidak produk tersebut jika dipakai, tanpa memilikirkan apakah dalam kosmetik tersebut secara signifikan tertera logo sebagai penjelasan dari kriteria produk yang digunakan. Memang jika diamati tidak semua produk kemasan memiliki logo bahkan jika memang memiliki logo, namun tidak semua logo tertera dalam kemasan tersebut. Masih seputar logo, jika konsumen telah mengetahui bahwa produk kosmetik yang digunakan tidak memiliki kelengkapan logo, apakah konsumen masih tetap membeli ulang produk yang sama atau berpaling keproduk yang lain. Sementara itu penelitian serupa yang dilakukan oleh (SAB, Vita 2014) Desain kemasan merupakan salah satu strategi perusahaan untuk dapat melakukan persaingan dalam dunia bisnis, selain itu untuk dapat menciptakan citra merek dalam benak konsumen yang bertujuan untuk menarik konsumen sebanyakbanyaknya sehingga konsumen melakukan keputusan pembelian terhadap produk tersebut. Hal yang menjadi kelebihan desain kemasan yang memang sangat diperhatikan oleh konsumen sebagai bahan pertimbangan mereka dalam melakukan keputusan pembelian, adalah sebagai berikut: ukuran dan bentuk dari kemasan, bahan dari kemasan, warna dari kemasan suatu produk, merek dan label yang terdapat pada kemasan. Unsur-unsur tersebut dianggap begitu penting bagi konsumen, dengan demikian konsumen pun dapat merasa terangsang untuk melakukan keputusan pembelian terhadap produk tersebut, sedangkan perusahaan menginginkan agar konsumen merasa puas terhadap desain kemasan yang telah diberikan oleh perusahaan kepada produk mereka, maka mereka pun terus berusaha untuk dapat memenuhi keinginan dan kebutuhan konsumen.

Kebutuhan ingin tampil cantik dan menarik membuat kebanyakan orang melakukan segalanya untuk memenuhi kebutuhan, salah satunya dengan kegiatan transaksi pembelian. Namun tentunya kegiatan pembelian ini harus di dukung oleh pengetahuan dari diri konsumen sehingga muncul istilah "Konsumen Cerdas". Jika konsumen merasa puas terhadap produk yang dibeli maka niat untuk membeli kombali produk yang sama mungkin saja terjadi. Hal serupa diterangkan dalam penelitian yang dilakukan 
oleh (SAB, Vita 2014) Kegiatan pembelian bisa dianggap sebagai kegiatan kosumen dalam memecahkan masalahnya.

Berdasarkan latarbelakang yang telah diuraikan diatas maka peneliti tetarik untuk mengaji lebih jauh "Pengaruh Logo Kemasan Produk Kosmetik Sebagai Penjelasan Kriteria Produk Pemakaian Dan Tingkat Pengetahun Kemasan Produk Terhadap Repurchase Intention"

\section{TINJAUAN PUSTAKA}

\section{Desain Logo}

Logo memiliki banyak istilah atau pengertian yang bervariasi. (Rustan 2009)dalam bukunya yang berjudul: Mendesain Logo, mengungkapkan bahwa logo adalah penyingkatan dari logotype. Istilah logotype ini dikenal lebih dulu dibandingkan kata logo pada tahun 1810-1840. Logotype diartikan sebagai tulisan nama entitas yang didesain secara khusus dengan menggunakan jenis huruf tertentu. Sehingga logotype pada mulanya hanya memuat tulisansaja.

Dari waktu ke waktu, logotype terus berkembang menjadi lebih unik dan berbeda. Logotype yang mulanya hanya memuat tulisan, kemudian ditambah dengan elemen gambar yang berbaur menjadi satu dengan tulisan. Hingga pada tahun 1937, istilah logo baru muncul hingga saat ini. (Shimp 2003) Hal yang berhubungan dengan nama merek adalah elemen desain grafis yang disebut logo merek. (Rustan 2009) juga menjelaskan bahwa logo bisa menggunakan elemen apa saja, seperti tulisan, logogram, gambar dan ilustrasi. Sedangkan kutipan dari Design Institute of Australia yang dimuat di buku Rustan yang berjudul 'Mendesain Logo', mengungkapkan bahwa logo merupakan sebuah simbol yang digunakan untuk mengidentifikasi perusahaan tanpa adanya kehadiran namaperusahaan.

Menurut (Pos 2015)logo lebih lazim dikenal oleh penglihatan, seperti ciri khas berupa warna dan bentuk logo tersebut. Menurut Brauchli dalam (Shimp 2003), tidak diragukan lagi bahwa logo menjadi peran komunikasi yang dapat berdampak pada citra dan penyadaran pada sebuah merek. Sehingga logo menjadi salah satu peran dalam strategi untuk pemasaran. Namun, (Shimp 2003)juga menambahkan bahwa pada era ini, strategi yang baik dalam membentuk sebuah logo adalah dengan memilih desain yang tidak terlalu simpel juga tidak terlalurumit. (Shimp 2003) secara umum suatu logo yang baik akan memiliki ciri-ciri:

1. Mudah dikenali dan juga untuk diingat kembali.

2. Secara esensial membawa arti yang sama bagi seluruh anggota sasaran

3. Menimbulkan suatu perasaan yang positif.
Berdasarkan penjelasan mengenai Logo maka dapat disimpulkan ukuran atau indokator dari sebuh logo meliputi:

1. Warna memiliki suatu arti dari suatu produk

2. Ilustrasi Gambar mampu memperjelas dan mempermudah pembaca memahami pesan

3. Elemen gambar dan tulisan mudah dibaca dimengerti

\section{Kemasan}

Menurut Gershman dalam (Shimp 2003)Peran komunikasi dari kemasan makin meningkat hingga menimbulkan ekspresi-ekspresi seperti " Pengemasan sekurang-kurangnya bentuk mahal dari iklan; "Seripa kemasan adalah iklan lima-detik"; dan "Kemasan adalah produk." (Shimp 2003)Kemasan juga berguna untuk:

1. Menggambarkan perhatian pada sebuah merek

2. Memisahkan merek dari kumpulan produk yang kompetitif pada poin-pembelian

3. Menyesuaikan harga/nilai bagi konsumen

4. Menandakan/mengartikan berbagai fitur dan keuntungan merek, dan akhirnya

5. Memotovasi pilihan merek konsumen

\section{Pengetahuan}

Pengetahuan adalah informasi yang dimiliki seseorang untuk bidang tertentu. Skor atau tes pengetahuan sering gagal untuk memprediksi kinerja SDM kerena skor tersebut tidak berhasil mengukur pengetahuan dan keahlian seperti apa yang seharusnya dilakukan dalam pekerjaan. Tes pengetahuan mengukur kemampuan peserta tes untuk me- milih jawaban yang paling benar, tetapi ti- dak bisa melihat apakah seseorang dapat melakukan pekerjaan berdasarkan pengeta- huan yang dimilikinya (Budi 2002)

Menumt (Blanchard 2004), pengetahuan dikategorikan sebagai berikut: (1) Informasi yang didapatkan dan diletakkan dalam ingatan kita (declarative). (2) Bagaimana informasi dikumpulkan dan digunakan ke sesuatu hal yang sudah kita ketahui (procedural). (3) Mengerti tentang how, when dan why informasi tersebut berguna dan dapat digunakan (strategic).

Pengetahuan mencerminkan kemampuan kognitif seorang karyawan berupa kemampuan untuk mengenal, memahami, me- nyadari dan menghayati suatu tugas/pekerjaan. Karena itu, pengetahuan seseorang kar- yawan dapat dikembangkan melalui pendidikan, baik formal maupun non formal serta pengalaman. Pendidikan membekali seseorang dengan dasar-dasar pengetahuan, teori, logika, pengetahuan umum, kemampuan analisis serta pengembangan watak dan kepri- badian (Robbins, Stephen P \& Judge 2009). 
Pengetahuan (knowledge) merupakan hasil dari tahu dan pengalaman seseorang dalam melakukan penginderaan terhadap suatu rangsangan tertentu. Pengetahuan tau kognitif merupakan dominan yang sangat penting dalam membentuk tindakan seseorang (overt behavior).

Kedalaman pengetahuan yang diperoleh seorang terhadap suatu rangsangan dapat diklasifikasikan berdasarkan enam tingkatan, yakni:

a. Tahu(know)

Merupakan mengingat suatu materi yang telah dipelajari sebelumnya, termasuk ke dalam tingkatan ini adalah mengingat kembali (recall) terhadap suatu spesifik dari seluruh bahan yang dipelajari atau rangsangan yang telah diterima. Oleh karena itu, tahu merupakan tingkatan pengalaman yang paling rendah.

b. Memahami (comprehension)

Merupakan suatu kemampuan untuk menjelaskan secara benar objek yang diketahui. Orang telah paham akan objek atau materi harus mampu menjelaskan, menyebutkan contoh, menyimpulkan, meramalkan, dan sebagainya terhadap objek yang dipelajari.

c. Aplikasi (application)

Kemampuan dalam menggunakan materi yang telah dipelajari pada situasi dan kondisi yang sebenarnya.

d. Analisis(analysis)

Kemampuan dalam menjabarkan materi atau suatu objek dalam komponen-komponen, dan masuk ke dalam struktur organisasi tersebut.

e. Sintesis(synthesis)

Kemampuan dalam meletakkan atau menghubungkan bagian-bagian di dalam suatu bentuk keseluruhan yang baru.

f. Evaluasi (evaluation)

Kemampuan dalam melakukan penilaian terhadap suatu materi atau objek (Notoatmodjo, 2005).

\section{Minat BeliUlang (Repurchase Intention)}

Minat beli dengan mengacu pada pendapat Doods dkk (Sutantio 2004) adalah kemungkinan pembeli berminat untuk membeli suatu produk. Sementara itu Howard dalam (Sutantio 2004) mengartikan intention to buy sebagai pernyataan yang berkaitan dengan batin yang mencerminkan rencana dari pembeli untuk membeli suatu merek tertentu dalam suatu periode waktu tertentu. Ferdinand dalam (Irzandy Mas Aga Haris 2017)menyatakan bahwa indikator minat beli antara lain; (1) minat transaksional, yaitu kecenderungan seseorang untuk membeli produk, (2) minat referensial, yaitu kecenderungan seseorang untuk mereferensikan produk kepada orang lain, (3) minat preferensial, yaitu minat yang menggambarkan perilaku seseorang yang memiliki preferensi utama pada produk tersebut, preferensi ini dapat berubah bila terjadi sesuatu dengan produk preferensinya, (4) minat eksploratif, minat ini menggambarkan perilaku seseorang yang selalu mencari informasi mengenai produk yang diminatinya dan mencari informasi untuk mendukung sifat-sifat positif dari produk tersebut.

\section{Kerangka Hipotesis}

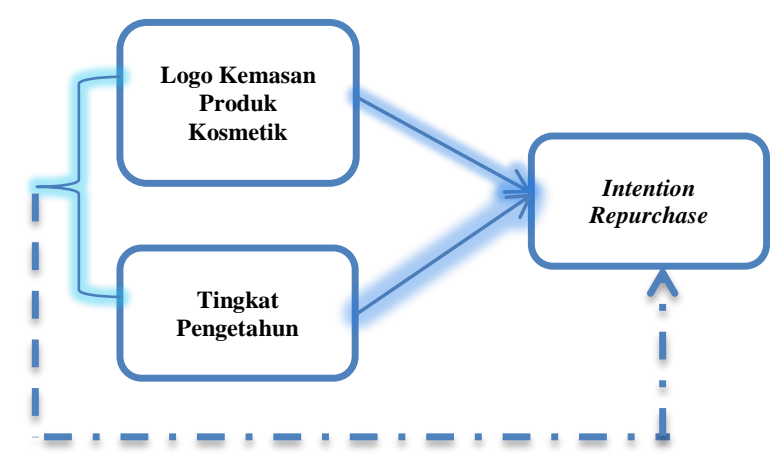

Gambar 2. Kerangka Hipotesis

\section{Hipotesis Penelitian}

Menurut Ary, Jacobs \& Sorensen dalam (Setyosari 2013) Pengertian atau definisi hipotesis seperti yang dikemukan oleh sebagai berikut, "A research hypothesis states the relationship one expects to find as a result of the research." Hipotesis penelitian itu menyatakan hubungan antara yang diharapkan dalam penelitian. Hubungan yang dimaksud adalah hubungan antara dua atau lebih variabel penelitian.

$\mathrm{H}_{0}$ : Tidak ada hubungan antara Logo Kemasan Produk Kosmetik terhadap Repurchase Intention

Ha: Ada hubungan antara Logo Kemasan Produk Kosmetik terhadap Repurchase Intention

$\mathrm{H}_{0}$ : Tidak ada hubungan antara Tingkat Pengetahuan Lintas terhadap Repurchase Intention

Ha: Ada hubungan antara Tingkat Pengetahuan Lintas terhadap Repurchase Intention

\section{METODE PENELITIAN}

Penelitian ini menggunakan tipe penelitian survei, sedangkan metode penelitian yang digunakan adalah kuantitatif.Menurut (Hamdi 2014)menjelaskan bahwa Penelitian Kuantitatif menekankan fenomenafenomena objektif dan dikaji secara kuantitatif. Maksimalisasi objektivitas desain penelitian ini dilakukan dengan menggunakan angka-angka, pengolahan statistik, struktur dan percobaan terkontrol. 


\section{Populasi dan Sampel}

Populasi merupakan kelompok elemen yang lengkap yang mana pada umumnyaberupa orang, objek, transaksi, atau kejadian dimana kita tertarik untuk mempelajarinyaatau menjadi objek penelitian (Yanti, Mery Oky Zufi dan Sukotjo 2016).

Berdasarkan data yang diperoleh Badan Pusat Stistik Prov. DKI Jakarta 2016 dari Jumlah penduduk menurut kecamatan, jenis kelamin dan rasio jenis kelamin 2015 diketahui jumlah penduduk kecamatan Koja Jakarta utara sebanyak 305.749.000. Dari jumlah populasi305.749.000 tersebut maka diambil sampel dengan menggunakan rumus Slovin. Penentuan besaran sampel dengan rumus slovin

Keterangan:

$$
n=\frac{N}{1+N e^{2}}
$$

$n=$ jumlah sampel

$N=$ jumlah populasi

$e=$ batas toleransi kesalahan (error tolerance)

$$
\begin{aligned}
\mathrm{n} & =\frac{305.749 .000}{1+305.749 .000 \times .0 .05^{2}} \\
& =\frac{305.749 .000}{305.749 .001 \times 0.0025} \\
& =\frac{305.749 .000}{746.372,502} \\
& =3999,999(400)
\end{aligned}
$$

\section{Variabel dan Pengukuran}

Penelitian yang digunakan dalam penelitian ini terdiri dari dua variabel bebas atau variabel independen dan satu variabel terikat atau variabel dependen. Menurut Ary dkk dalam (Setyosari 2013)ada sejumlah batasan atau definisi variabel penelitianmen definisikan variabel sebagai berikut, "A variable is a construct or a characteristic that can take on different values or scores,".

Menurut Fraenkel, Wallen, \& Hyun dalam (Setyosari 2013) dalam menjelaskan pengertian variabel sebagai berikut, "A variable is a concept- a noun that stands for variation within a class of objects." Menurut pendapat mereka, bahwa suatu variabel adalah suatu konsep-suatu objek yang memiliki variasi dalam kelompok objek. Pengertian ini sejalan dengan batasan yang dikemukakan oleh Ary dkk, tersebut. Varibel atau faktor peneliltian memiliki peranan sangat penting dalam suatu penelitian, dalam hal ini khusus penelitian pendidikan.

Menurut (Setyosari 2013)Variabel Bebas yang juga disebut sebagai varibel stimulus atau masukan, dilakukan oleh seseorang dalam lingkungannya yang dapat memengaruhi perilaku hasil.
Menurut (Setyosari 2013) Variabel terikat atau variabel dependen adalah suatu variabel respons atau hasil. Varibel ini adalah aspek perilaku yang diamati dari organisme yang telah diberi stimulasi.

Dalam penelitian ini pengukuran yang dipergunakan adalah skala bertingkat model Likert dengan 5 alternatif jawaba. Agar data yang diperoleh berwujud data kuantitatif, maka setiap butir soal diberi skor sesuai jawabannya yaitu,

- Sangat Tidak Setuju =1

- Tidak setuju $=2$

- Kurang Setuju $=3$

- Setuju $=4$

- Sngat Setuju $=5$ (Sugiyono, 2004)

\section{ANALISA DAN PEMBAHASAN}

Berdasarkan data yang diperoleh dari BPS. Dari besaran populasi tersebut lalu diambilah sampel dengan menggunakan rumus slovin. Maka dari hasil perhitungan menggunakan rumus slovin didapatkan jumlah responden yang tinggal di kecamatan koja Jakarta Utara berjumlah 400 orang. Setelah itu data responden dibedakan lagi menjadi jenis kelamin dan pendidikan.

Berdasarkan hasil perhitungan menggunakan SPSS 24 menjukkan untuk jumlah responden lakilaki berjumlah 115 orang atau sekitar $28,7 \%$. Sementara itu untuk jumlah responden perempuan berjumlah 285 orang atau sekitar $71,3 \%$ dengan jumlah total keseluruhan 400 orang.

Sementara itu untuk jumlah responden berdasarkan pendidikan dibedakan menjadi empat yaitu SMP, SMA, Diploma (D3), Sarjana (S1), dan Pascasarjana (S2). Dengan jumlah SMP sebanyak 25 orang atau sekitar 6,3\%, jumlah SMA sebanyak 242 orang atau sekitar 60,5\%, Dimploma. (D3) sebanyak 25 orang atau sekitar 6,3\%, Sarjana (S1) sebanyak 97 orang atau sekitar 24,3\%, Pascasarjana (S2) sebanyak 11 orang atau sekitar $2,8 \%$.

\section{Uji Validitas dan Uji Realibilitas}

Uji validitas digunakan untuk mengetahui kelayakan butir-butir dalam suatu daftar (konstruk) pertanyaan dalam mendefinisikan suatu variabel. Validitas didefinisikan sebagai sejauh mana ketepatan dan kecermatan suatu alat ukur dalam melakukan fungsi ukurnya (Tim Penyusun).

Berdasarkan hasil uji terhadap semua butir pertanyaan $\mathrm{X} 1, \mathrm{X} 2$, Y menujukkan bahwa kesemua butir pertanyaan atau $r$ hitung lebih besar dari $r$ tabel 0,098 sehingga dapat dikatakan memenuhi syarat validitas. 
Sementara itu untuk uji realibiltas diketahui bahwa nilai Cronbach Alpha mendekati satu (1) menujukkan bahwa pengukuran yang dipakai benarbenar telah mengukur apa yang hendak diukur. Untuk menginterprestasikan Koefisien Korelasi (KK) realibilitas, ditentukan dengan kriteria sebagai berikut (Hasan 2004):

1. $\mathrm{KK}=1$ : sempurna

2. Antara 0,900 sampai dengan $1,000=$ sangat tinggi

3. Antara 0,700 sampai dengan $0,900=$ tinggi atau kuat

4. Antara 0,400 sampai dengan $0,700=$ cukup tinggi

5. Antara 0,200 sampai dengan $0,400=$ rendah atau lemah tetapi pasti

6. Antara 0,000 sampai dengan $0,200=$ sangat rendah atau lemah sekali

7. $\mathrm{KK}=0$ : Tidak Ada

Berdasarkan hasil perthitungan realibilitas didapatkan bahwa dari ketiga variabel yaitu Logo Kemasan Produk Kosmetik (X1) mimiliki nilai realibilitas 0.923, Tingkat Pengetahuan (X2) mimiliki nilai realibilitas 0.918 , dan Repurchase Intention (Y) mimiliki nilai realibilitas 0.913 maka dapat disimpulkan bahwa Cronbach Alpha $\square$ 0,900 dengan kriteria realibilitas sangat tinggi.

\section{Uji Regresi Linier Berganda}

Tabel 1. Uji Regresi

\begin{tabular}{cc|c|c|c}
\multicolumn{5}{c}{ Model Summary $^{\mathrm{b}}$} \\
\hline Model & $\mathbf{R}$ & R Square & $\begin{array}{c}\text { Adjusted R } \\
\text { Square }\end{array}$ & $\begin{array}{c}\text { Std. Error of } \\
\text { the Estimate }\end{array}$ \\
\hline 1 & $.996^{\mathrm{a}}$ & .992 & .992 & .358 \\
\hline
\end{tabular}

a. Predictors: (Constant), Tingkat Pengetahuan (X2), Logo Kemasan Kosmetik (X1)

b. Dependent Variable: Intention Repurchase (Y)

Sumber: Data yang diolah dengan SPSS 25 (2018)

Berdasarkan hasil regresi linier didapatkan nili $\mathrm{R}$ sebesar 0,996 menunjukkan korelasi ganda (Logo Kemasan Produk Kosmetik dan Tingkat Pengetahuan) dengan Repurchase Intention.

Nilai Ajustes R Square didapatkan sebesar 0,992 menujukkan besarnya sumbangan pengaruh atau kontribusi Logo Kemasan Produk Kosmetik (X1), Tingkat Pengetahuan (X2), sebesar 99,2\% (0,992 x $100 \%$ ) sementara itu sisanya dipengaruhi variabel lain yang tidak diteliti, dalam penelitian ini.

\section{Uji F}

Menurut (Herjanto 2015) Uji-F dipakai untuk melihat pengaruh variabel-variabel bebas secara keseluruhan terhadap variabel tak bebas. Pengujian ini dilakukan dengan membandingkan $F_{\text {hitung }}$ dengan $\mathrm{F}_{\text {tabel. }}$. Berdasarkan hasil perhitungan didapatkan Nilai F tabel sebesar 3,01 karena nilai F hitung 23742.526 lebih besar dari nilai $\mathrm{F}$ tabel 3,01 maka dapat ditarik keseimpulan bahwa variabel bebas X1 (Logo Kemasan Produk Kosmetik) dan X2 (Tingkat Pengetahuan) secara bersama berpengaruh terhadap variabel terikat Y (Repurchase Intention).

\section{Uji t}

Tabel 2. Uji t

\begin{tabular}{|c|c|c|c|c|c|c|c|c|}
\hline \multicolumn{9}{|c|}{ Coefficients $^{\mathrm{a}}$} \\
\hline & \multirow[t]{2}{*}{ Model } & \multicolumn{2}{|c|}{$\begin{array}{l}\text { Unstandardi } \\
\text { zed } \\
\text { Coefficients }\end{array}$} & \multirow{2}{*}{$\begin{array}{c}\begin{array}{c}\text { Standar } \\
\text { dized } \\
\text { Coeffic } \\
\text { ients }\end{array} \\
\text { Beta }\end{array}$} & \multirow[t]{2}{*}{$\mathrm{t}$} & \multirow[t]{2}{*}{ Sig. } & \multicolumn{2}{|c|}{$\begin{array}{c}\text { Collinearity } \\
\text { Statistics }\end{array}$} \\
\hline & & B & $\begin{array}{l}\text { Std. } \\
\text { Error }\end{array}$ & & & & $\begin{array}{l}\text { Toler } \\
\text { ance }\end{array}$ & VIF \\
\hline \multirow[t]{3}{*}{1} & (Constant) & .546 & .151 & & 3.621 & .000 & & \\
\hline & $\begin{array}{l}\text { Logo Kemasan } \\
\text { Kosmetik (X1) }\end{array}$ & .137 & .016 & .143 & 8.345 & .000 & .071 & $\begin{array}{c}14.15 \\
2\end{array}$ \\
\hline & $\begin{array}{l}\text { Tingkat } \\
\text { Pengetahuan } \\
\text { (X2) }\end{array}$ & .848 & .017 & .857 & 49.838 & .000 & .071 & $\begin{array}{c}14.15 \\
2\end{array}$ \\
\hline
\end{tabular}

a. Dependent Variable: Intention Repurchase (Y)

Sumber: Data yang diolah dengan SPSS 25 (2018)

Menurut (Priyatno 2013) Uji t untuk mengetahui pengaruh variabel independen secara parsial terhadap variabel dependen, apakah pengaruhnya signifikan atau tidak.

Pengujian b1 (Logo Kemasan Kosmetik) Pengaruh Logo Kemasan Kosmetik Terhadap Repurchase Intention. Tahap-tahap pengajuan sebagai berikut:

a. Menentukan hipotesis nol dan hipotesis alternatif $\mathrm{H} 0: \mathrm{b} 1=0$

b. Artinya Logo Kemasan Kosmetik tidak berpengaruh terhadap Repurchase Intention.

Ha $: b 1 \neq 0$

Artinya Logo Kemasan Kosmetik berpengaruh terhadap Repurchase Intention.

c. Menentukan taraf signifikansi. Taraf signifikansi menggunkan 0,05 .

d. thitung dan $t$ kritis thitung adalah 8,345 (lihat di tabel Coefficients) t kritis dapat dicari pada tabel statistik pada signifikansi 0,05/2 $=0,025$ (uji 2 sisi) dengan $\mathrm{df}=$ n-k-1 atau 400-2-1 =397 ( $\mathrm{k}$ adalah jumlah variabel independen). Di dapat $t$ kritis 1,966

e. Pengambilan keputusan

Thitung $\leq \mathrm{t}$ kritis jadi $\mathrm{H} 0$ diterima

T hitung $>\mathrm{t}$ kritis jadi $\mathrm{H} 0$ ditolak

Kesimpulan

f. Dapat diketahui bahwa t hitung $(8,345>t$ kritis $(1,966)$ jadi hipotesis nol ditolak, kesimpulannya yaitu Hipotesis 1 menujukkan Logo Kemasan Kosmetik berpengaruh terhadap Repurchase 
Intention. Nilai koefisien dan t hitung adalah positif sehingga Logo Kemasan Kosmetik berpengaruh positif terhadap Repurchase Intention.

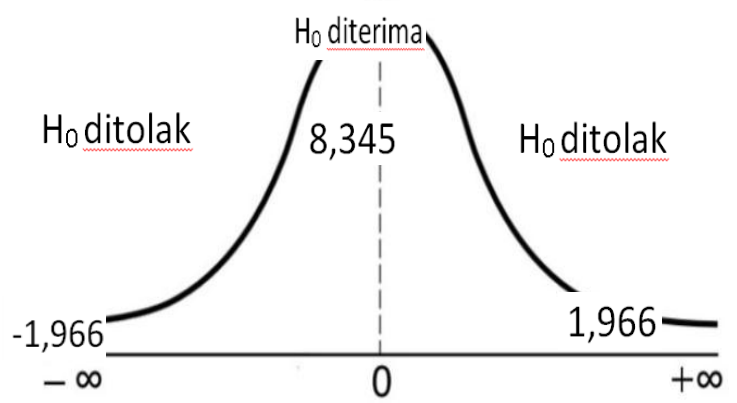

Gambar 3. Distribusi Normal Uji t

Pengambilan keputusan berdasarkan Probabilitas (Signifikansi) Pengaruh Pengetahuan Terhadap Repurchase Intention.

a. Menentukan hipotesis nol dan hipotesis alternatif $\mathrm{H} 0: \mathrm{b} 2=0$

Artinya Logo Kemasan Kosmetik tidak berpengaruh terhadap Repurchase Intention

$\mathrm{Ha}: \mathrm{b} 2 \neq 0$

Artinya Logo Kemasan Kosmetik berpengaruh terhadap Repurchase Intention

Menentukan probalibilitas (signifikasi) berdasarkan tabel Coefficients dapat diketahui probabilitas adalah 0,000

b. Pengambilan keputusan

Probabilitas $>0,05$ jadi $\mathrm{H} 0$ diterima

Probabilitas $\leq 0,05$ jadi $\mathrm{H} 0$ ditolak

c. Kesimpulan

Dapat diketahui bahwa Probabilitas sebesar 0,000 lebih kecil dari 0,05 maka hipotesis nol ditolak, kesimpulannya yaitu Hipotesis 2 menujukkan Logo Kemasan Kosmetik berpengaruh terhadap Repurchase Intention. Gambar 4.5 Distribusi Normal Uji t

Pengujian b2 (Pengetahuan) Tahap-tahap pengujian sebagai berikut:

a. Menentukan hipotesis nol dan hipotesis alternatif $\mathrm{H} 0: \mathrm{b} 2=0$

Artinya Pengetahuan tidak berpengaruh terhadap Repurchase Intention.

Ha $:$ b2 = 0

Artinya Pengetahuan berpengaruh terhadap $R e$ purchase Intention.

b. Menentukan taraf signifikansi. Taraf signifikansi menggunakan 0,05 .

c. thitung dan $t$ kritis

$\mathrm{t}$ hitung $\mathrm{t}$ hitung adalah 1,042 (lihat di tabel Coefficients) t kritis dapat dicari adalah 1,042 (lihat di tabel Coefficients)padatabel statistik pada signifikansi $0,05 / 2=0,025$ (uji 2 sisi) dengan $\mathrm{df}=\mathrm{n}-\mathrm{k}-1$ atau 400-2-1 = 397. Didapat t kritis adalah 1,966.

d. Pengambilan keputusan thitung $\leq \mathrm{t}$ kritis jadi $\mathrm{H} 0$ diterima thitung $>\mathrm{t}$ kritis jadi $\mathrm{H} 0$ ditolak

e. Kesimpulan Dapat diketahui bahwa $t$ hitung $(49,838)>t$ kritis $(1,966)$ jadi hipotesis nol diterima, kesimpulannya yaitu Pengetahuan berpengaruh terhadap Repurchase Intention.

Nilai koefisien dan t hitung adalah positif sehingga Pengetahuan berpengaruh positif terhadap Repurchase Intention.

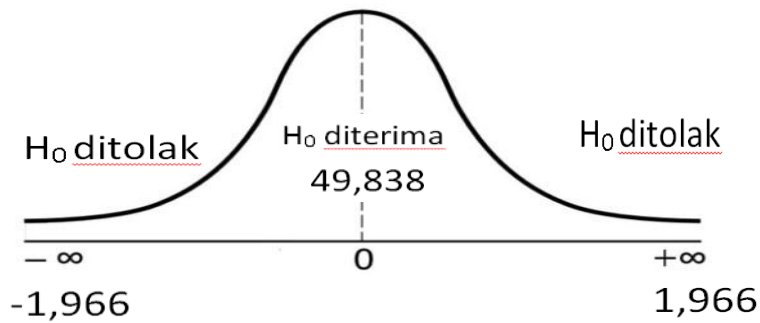

Gambar 4. Distribusi Normal Uji t

Pengambilan keputusan berdasarkan Probabilitas (Signifikansi)

a. Menentukan hipotesis nol dan hipotesis alternatif $\mathrm{H} 0: \mathrm{b} 2=0$

Artinya Pengetahuan tidak berpengaruh terhadap Repurchase Intention.

Ha : b2 $\neq 0$

Artinya Pengetahuan berpengaruh terhadap $R e$ purchase Intention.

b. Menentukan probalibilitas (signifikasi) berdasarkan tabel Coefficients dapat diketahui probabilitas adalah 0,000

Probabilitas $>0,05$ jadi $\mathrm{H} 0$ diterima

c. Pengambilan keputusan

Probabilitas $\leq 0,05$ jadi H0 ditolak

d. Kesimpulan

Dapat diketahui bahwa Probabilitas sebesar 0,000 lebih kecil dari 0,05 maka hipotesis nol ditolak, kesimpulannya yaitu Pengetahuan berpengaruh terhadap Repurchase Intention.

\section{Uji Heteroskedastisitas}

Menurut (Wijaya 2012) menjelaskan bahwa dengan Melihat sebaran titik-titik yang acak baik di atas maupun di bawah angka 0 dari sumbu Y, dapat disimpulkan dari gambar 4.1.dibawah ini tidak terjadi Heteroskedastisitas dalam model regresi ini. 


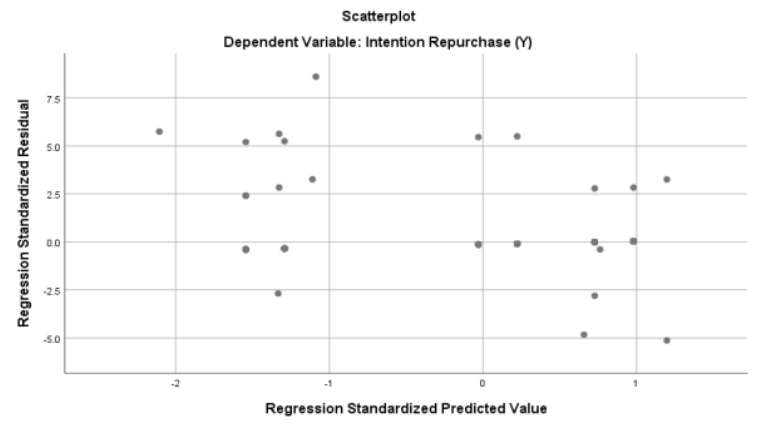

Gambar 5. Uji Heteroskedastisitas

\section{Pembahasan}

Pengaruh Logo Kemasan Kosmetik Terhadap Repurchase Intention berpengaruh positif hal ini didukung oleh penelitian Iranita dalam (Rizal 2016) yang menggambarkan bahwa semakin tinggi Logo Kemasan Kosmetik maka semakin meningkat Repurchase Intention, atau semakin besar Repurchase Intention, maka semakin meningkat Logo Kemasan Kosmetik. Hal serupa juga didukung oleh penelitian yang dilakukan oleh (Widyaningrum 2016) yang menyimpulkan bahwa semakin tinggi Logo Kemasan Kosmetik maka akan semakin tinggi Repurchase Intention.

Berdasarkan penelitian yang dilakukan oleh Lin dan Lin dalam (Suarjana, I Kadek dan Suprapti 2018), dapat disimpulkan bahwa konsumen dengan pengetahuan produk yang tinggi akan menilai produk berdasarkan kualitasnya karena mereka yakin dengan pengetahuan yang mereka miliki. Oleh karena itu, konsumen biasanya akan sadar tentang nilai sebuah produk sehingga niat belinya pun meningkat.

Sementara itu Pengetahuan berpengaruh secara signifikan terhadap Repurchase Intention. Hal ini didukung oleh penelitian yang dilakukan oleh Penelitian serupa juga dilakukan oleh (Resmawa 2017), pengetahuan memiliki pengaruh yang signifikan terhadap purchase intention Untuk itu, semakin tinggi pengetahuan konsumen terhadap produk, maka semakin mendukung intensi pembelian konsumen pada produk. Hal ini bisa diartikan bahwa pengetahuan konsumen terhadap produk mendasari intensi pembelian konsumen pada produk produk.

\section{SIMPULAN DAN SARAN}

Berdasarkan hasil yang telah diuji maka dapat di ambil kesimpulan bahwa Logo Kemasan Kosmetik berpengaruh terhadap Repurchase Intention. Nilai koefisien dan t hitung adalah positif sehingga Logo Kemasan Kosmetik berpengaruh positif dan signifikan terhadap Repurchase Intention.
Sementara itu untuk Pengetahuan berpengaruh terhadap Repurchase Intention. Nilai koefisien dan $\mathrm{t}$ hitung adalah positif sehingga Pengetahuan berpengaruh positif dan signifikan terhadap Repurchase Intention.

Berdasarkan penelitian ini maka saran terhadap konsumen yang dalam ini khususnya masyarakat $\mathrm{Tj}$. Priok Kelurahan Lagoa Cakarawala 1 \& II adalah lebih waspada dan memperhatikan kelengkapan logo penggunaan atau keterangan lain yang tercantuk di kosmetik. Sementara itu bagi produsen yang memproduksi kosmetik sebaiknya tidak hanya memilikirkan keutungan semata namun juga kesehatan pengguna/konsumen, peduli terhadap lingkungan dan binatang, dengan tidak melakukan uji coba terhadap binate yang dalam hal ini sering kali kelinci digunakan sebagai sampel penelitian.

\section{DAFTAR PUSTAKA}

Blanchard, P. Nick James W. Thacker. 2004. Effective Training: System, Strategy and Practices, 2nd Edition. New Jersey: Pearson Prentice Hall.

Budi, W. Soetjipto dkk. 2002. Paradigma Baru Manajemen Sumber Daya Manusia. Editor. Yogyakarta: Amara Books.

Hamdi, Asep Saepul \& E. Bahrudin. 2014. Metode Penelitian Kunatitatif Aplikasi Dalam Pendidikan. Yogyakarta: Depublish.

Hasan, Iqbal. 2004. Analisis Data Penelitian Dengan Statistik. Jakarta: Bumi Aksara.

Herjanto, Eddy. 2015. Manajemen Operasi. Jakarta: Grasindo.

Irzandy Mas Aga Haris, dkk. 2017. "Pengaruh Ekuitas Merek Terhadap Minat Beli Dan Dampaknya Pada Keputusan Pembelian." Jurnal Administrasi Bisnis (JAB) Vol. 51: Hal 151-158.

Kaihatu, Thomas S. 2014. Manajemen Pengemasan. Yogyakarta: ANDI.

Pos, Iklan. 2015. "No Title," 2015.

Priyatno, Duwi. 2013. Analisis Korelasi, Regresi Dan Multivariate Dengan SPSS. Yogyakarta: Gava Media.

Resmawa, Ira Ningrum. 2017. "Pengaruh Brand Image Dan Product Knowledge Terhadap Purchase Intention Dengan Green Price Sebagai Moderating Variabel Pada Produk the Body Shop Di Surabaya" Vol. 1, No: Hal 1-11, ISSN 2541-1438; E-ISSN 2550-0783.

Rizal, Muhammad. 2016. "Pengaruh Labelisasi Halal Terhadap Keputusan Pembelian Sosis Di Kuala Simpang Kabupaten Aceh Tamiang." Jurnal Manajemen Dan Keuangan VOL.5, NO.: Hal 430-439. 
Robbins, Stephen P \& Judge, Timothy A. 2009. Perilaku Organisasi. Jakarta: Salemba Empat.

Rustan, Surianto. 2009. Mendesain Logo. Jakarta: Gramedia Pustaka Utama.

SAB, Vita, Dhameria. 2014. "Analisis Pengaruh Keunikan Desain Kemasan Produk, Kondusivitas Store Environment, Kualitas Display Produk Terhadap Keputusan Pembelian Impulsif (Studi Pada Pasaraya Sri Ratu Pemuda Semarang). Kan Desain.” Jurnal Sains Pemasaran Indonesia Volume XII: Hal 1-44.

Setyosari, Punaji. 2013. Metode Penelitian Dan Pengembangan. Jakarta: Prenadamedia Group.

Shimp, Terence A. 2003. Periklanan Promosi Dan Aspek Tambahan Komunikasi Pemasaran Terpadu. Jakarta: Erlangga.

Suarjana, I Kadek dan Suprapti, Ni Wayan Sri. 2018. "Pengaruh Persepsi Harga, Pengetahuan Produk, Dan Citra Perusahaan Terhadap Niat Beli Layanan Multi Servis Merek Indihome.” EJurnal Manajemen Unud Vol. 7, No: hal 19201949, ISSN : 2302-8912.
Susetyarsi, Th. 2017. "Kemasan Produk Ditinjau Dari Bahan Kemasan, Bentuk Kemasan Dan Pelabelan Pada Kemasan Pengaruhnya Terhadap Keputusan Pembelian Pada Produk Minuman Mizone Di Kota Semarang." Jurnal STEI Semarang Vol 4,: Hal 19-28, ISSN 2252-7826.

Sutantio, Magdalena. 2004. "Studi Mengenai Pengembangan Minat Beli Merek Ekstensi; Studi Kasus Produk Sharp Di Surabaya,." Jurnal Sains Pemasaran Indonesia III.

Widyaningrum, Premi Wahyu. 2016. "Pengaruh Label Halal Dan Celebrity Endorser Terhadap Keputusan Pembelian (Survei Pada Konsumen Wardah Di Ponorogo)." Jurnal Ekonomi Syariah Indonesia Volume VI,: Hal 83-98.

Wijaya, Tony. 2012. Cepat Menguasai SPSS 20 Untuk Olah Data Interprestasi Data. Yogyakarta: Cahaya Atma Pustaka.

Yanti, Mery Oky Zufi dan Sukotjo, Hendri. 2016. "Pengaruh Kesadaran Merek, Asosiasi Merek, Dan Brand Image Terhadap Keputusan Pembelian Aqua." Jurnal Ilmu Dan Riset Manajemen Volume 5,: 1-15 ISSN : 2461-0593. 